\title{
A study on incidence of Epidermal Tumors
}

\author{
1.Dr. B.Venkata Sai Prasad ${ }^{1}$, Dr. Sreedhar.Bora ${ }^{2}$, Dr.L.Krishna, ${ }^{3}$, \\ Dr.B.Anuradha ${ }^{4}$, Dr.E.S. Reddy ${ }^{5}$, \\ ${ }^{1,2}$ Associate Professor, Dept of Pathology, S.V. Medical College, Tirupati, Andhra Pradesh. \\ ${ }^{3,4}$ Professor, Dept of Pathology, S.V. Medical College, Tirupati, Andhra Pradesh. \\ ${ }^{5}$ Professor, Dept of Pathology, ACS Govt Medical College, Nellore, Andhra Pradesh.
}

\begin{abstract}
:
Introduction: A skin tumor encompasses a vast area of pathology, because skin is a heterogeneous organ with many varied elements having ectodermal and mesodermal origins. The surface epidermis tumors are the most common group of neoplasms. The most of the tumors appears as sebaceous cysts but FNAC and Histopathology examination is the confirmatory. The present study confirmed many tumors.

Methods: The total 1332 tumors which are registered for Histo pathology examination are taken as a Study group. The study is retrospective and prospective with regard to skin tumors. The skin tumors collected over a period of 4 years from the Department of Pathology, S.V.Medical College, Tirupati and diagnosed. The paraffin embedded present and previous blocks collected and cut to 5 micron sections and stained routinely with haematoxylin and eosin and examined microscopically for establishing the precise nature of lesions.

Results : - About 1332 were the number of total tumors recorded in the Department of Pathology, out of these number of skin tumors were 114, giving incidence of 8.6\%. Among the total skin tumors of 114, the epidermal tumors are 80 and incidence rate is 68\%. The surface epidermis tumors were the predominant group with incidence of $69 \%$ followed by adnexal tumors with $26 \%$ incident and the least incidence shown by melonogenic tumors of $14 \%$ incidence. Among the skin tumors recorded with the study are majority of the lesions occurred between the $5^{\text {th }}, 6^{\text {th }}$, and $4^{\text {th }}$ decades giving incidence of $24.94 \%, 19.78 \%$ and $18.92 \%$ with peak age incidence between 41-50 years. Benign skin tumors displayed peak incidence in the forth decade.

Conclusion: - out of a total of 1332 the skin tumors are 114(8.6\%) were skin tumors accounting for 114 cases (99.56\%) and secondary deposits accounted for only 1 case (0.86\%) and unclassified 1 case $0.86 \%$.
\end{abstract}

Keywords: - skin tumors- Epidermal tumors-Age, sex and site incidence.

\section{Introduction}

The Skin appendageal tumors encompass a wide variety of tumors clinically presenting as papules and nodules with histological distinct features. Benign tumors of epidermal origin are among the most common lesions arising from the skin. As the skin is the heterogeneous organ it produces many epithelial tumors. The scientific inquiry has revealed skin as a complex organ in which precisely regulated cellular interactions govern many crucial responses to our environment. In spite of growing public awareness of harmful effects of sun exposure, incidence of Skin tumors continues to rise. Skin tumors are associated with substantial morbidity, disfigurement and their treatment is costly. Early diagnosis can reduce morbidity and cost. As per the W.H.O classification epithelial tumors and tumor like lesions are 1.Basal Cell Carcinoma with sub types of superficial multicentric type, Morphea type, Fibroepithelial. 2 Squmous cell Carcinoma with sub types of Adenoid squmous cell carcinoma and spindle cell type carcinoma 3 Metatypical carcinoma and Inverted follicular Keratosis and other types are Pagets disease and undifferentiated Carcinoma. Benign epidermal tumors are localised and systematised and shows picture of benign papilloma, hyperkeratosis, papillomatosis and acanthosis with elongation of rete ridges. Seborrheic Keratosis commomly occurs over the trunk ,face and extremities and usually occurs during middle age. Gross appearance shows slightly raised looks as if they are stuck to the surface of skin and consistency is soft and frible. Histology shows hyperkeratosis, acanthosis and papillomotosis. Bowens disease is a solitary lesion and occur on exposed or un exposed parts of the body and manifests as a slowly embrasing erythematous patch of sharp with irregular outline, histologically epidermis shows acanthosis with elongation and thickening of the rete ridges. Many cells appear highly atypical showing large hyper chromatic nuclei and horny layer usually thickened and consists largely of parakeratotic cells with atypical, hyper chromatic nuclei.

Basal Cell Carcinoma is a locally invasive, slowly spreading skin tumor with extremely variable clinical presentation, considered to have origin from the folliculo sebaceous-apocrine germ also known as trichoblast. BCC also called Basiloma, Rodent Ulcer, Basal Cell Epithelioma. Overexposure to sun leads to the formation of thymine dimmers a form of DNA damage, cumulative DNA damage leading to mutations. Apart from the mutagenesis, over exposure sunlight depresses the local immune system and for developing new tumor 
cells. Biological behaviour and histology and conflicting versons on histology whether arising from basal cells of epidermis appendages or displaced embryonic primordial of epidermal appendages. Different types of Basal cell carcinoma are classified. Undifferentiated type are called as solid type and characterised by strands of irregular shaped masses of tumor cells within the dermis and differentiated type show a slight degree of differentiation on towards the Cutaneous appendages. Keratotic type shows horn cyst filled with lamellar karatin and bordered by flattened parakeratotic cells with tumor islands. In Adenoid type cells arranged in intertwining strands and radially around islands of connective tissue. Cystic Type shows one or several cystic spaces within the tumor lobules.Morphologically the Epidermal tumors look similar and the great majority are not diagnosed as such until after excision and pathological study.

\section{Methods}

The material presented here consists of skin tumors collected over a period of four year (1994-1997) from the Department of Pathology S.V.Medical College, Tirupati. The tumors which were excised and sent for the Histopathology examination are taken for the study and examined thoroughly with Histopathology. About 1332 tumors of both benign and malignant tumors were examined. Representative sections were given and fixed in $10 \%$ formalin solution and studied with histopathological examination. Tissues thus selected were subjected to automatic processing: blocks were made out of 6-8 microns and stained with haematoxylin, Eosin and Special stains were employed- PAS Stain, Alcian Blue -Stain and Lipid Stain. The bits are subjected for Histopathology examination. The grossing and automatic processing, block making and reporting was done in the Dept of Pathology, S.V. Medical College, Tirupati. The results were statistically analysed.

\section{Results}

The results are shown in various tables and discussed.

Table 1: Ratio of Benign and Malignant Tumors

\begin{tabular}{|l|l|l|l|}
\hline $\begin{array}{l}\text { Total No of Tumors } \\
\text { among } \begin{array}{c}\text { Surgical } \\
\text { Pathology speciality }\end{array}\end{array}$ & Total number of skin tumors & $\%$ of skin tumors among general & $\begin{array}{l}\text { Average Incidence of Skin } \\
\text { tumors per year }\end{array}$ \\
\hline 1332 & 114 & 8.6 & 29 \\
\hline
\end{tabular}

Table 2: Incidence of Epidermal Tumors

\begin{tabular}{|l|l|l|}
\hline Total Skin Tumors & Epidermal Tumors & Incidence \\
\hline 114 & 80 & $68 \%$ \\
\hline
\end{tabular}

Table 3: Percentage of Benign and Malignant Tumors

\begin{tabular}{|l|l|l|l|l|}
\hline Total Epidermal Tumors & Benign Tumors & \% of Benign Tumors & Malignant Tumors & $\%$ of Malignant Tumors \\
\hline 80 & 25 & 21.5 & 54 & 46.4 \\
\hline
\end{tabular}

Table 4: Incidence of Various Epidermal Skin Tumors

\begin{tabular}{|l|l|l|}
\hline \multicolumn{1}{|c|}{ Type of Tumor IV } & No of Epidermal Tumors & Percentage of Specific Category \% \\
\hline Squmous papilloma & 19 & $16.34 \%$ \\
\hline Seborrheic Keratosis & 6 & $5.16 \%$ \\
\hline Bowens disease & 1 & $86 \%$ \\
\hline Squmous Cell Carcinoma & 41 & $35.26 \%$ \\
\hline Basal cell Carcinoma & 13 & $11.18 \%$ \\
\hline
\end{tabular}

Table 5: Age Incidence of Individual Skin Tumors

\begin{tabular}{|l|l|l|l|l|l|l|l|l|l|}
\hline $\begin{array}{l}\text { Tumors of } \\
\begin{array}{l}\text { Surface } \\
\text { Epidermis }\end{array}\end{array}$ & Total & $\begin{array}{l}0-10 \\
\%\end{array}$ & $\begin{array}{l}11-20 \\
(\%)\end{array}$ & $\begin{array}{l}21-30 \\
(\%)\end{array}$ & $\begin{array}{l}31-40 \\
(\%)\end{array}$ & $\begin{array}{l}41-50 \\
(\%)\end{array}$ & $\begin{array}{l}51-60 \\
(\%)\end{array}$ & $\begin{array}{l}61-70 \\
(\%)\end{array}$ & $\begin{array}{l}71-80 \\
(\%)\end{array}$ \\
\hline $\begin{array}{l}\text { Squmous } \\
\text { Papillomas }\end{array}$ & 19 & - & $\begin{array}{l}2 \\
(1.72)\end{array}$ & $\begin{array}{l}7 \\
(5.82)\end{array}$ & $\begin{array}{l}8 \\
(6.88)\end{array}$ & $\begin{array}{l}1 \\
(0 / 86)\end{array}$ & $\begin{array}{l}1 \\
(0.86)\end{array}$ & - \\
\hline $\begin{array}{l}\text { Seborrheic } \\
\text { Keratosis }\end{array}$ & 6 & - & - & $\begin{array}{l}1 \\
(0.80)\end{array}$ & $\begin{array}{l}1 \\
(0.86)\end{array}$ & $\begin{array}{l}1 \\
(0.86)\end{array}$ & $\begin{array}{l}2 \\
(1.72)\end{array}$ & $\begin{array}{l}1 \\
(0.86)\end{array}$ & - \\
\hline $\begin{array}{l}\text { Bowens disease } \\
\text { Bow }\end{array}$ & 1 & - & - & $\begin{array}{l}5 \\
(4.30)\end{array}$ & - & $\begin{array}{l}1 \\
(0.86)\end{array}$ & - & - & - \\
\hline $\begin{array}{l}\text { Squmous cell } \\
\text { Carcinoma }\end{array}$ & 41 & - & - & - & $\begin{array}{l}4 \\
(3.44)\end{array}$ & $\begin{array}{l}15 \\
(12.90)\end{array}$ & $\begin{array}{l}11 \\
(9.46)\end{array}$ & $\begin{array}{l}6 \\
(5.16)\end{array}$ & - \\
\hline $\begin{array}{l}\text { Basal Cell } \\
\text { Carcinoma }\end{array}$ & 11 & - & - & $\begin{array}{l}2 \\
(1.72)\end{array}$ & $\begin{array}{l}2 \\
(1.72)\end{array}$ & $\begin{array}{l}1 \\
(0.86)\end{array}$ & $\begin{array}{l}3 \\
(2.58)\end{array}$ & $\begin{array}{l}2.58) \\
(1.76)\end{array}$ \\
\hline
\end{tabular}


Table 6: Male and Female ratio of epidermal tumors

\begin{tabular}{|c|c|c|c|c|}
\hline \multirow[t]{2}{*}{ Type of the tumour } & \multirow[t]{2}{*}{ Total } & \multicolumn{2}{|l|}{ Sex } & \multirow{2}{*}{$\begin{array}{l}\text { Male : Female } \\
\text { Ration }\end{array}$} \\
\hline & & Male & Female & \\
\hline \multicolumn{5}{|l|}{ Tumors of surface epidermis } \\
\hline 1.Squamous papillomas & 19 & 14 & 5 & $2.9: 1$ \\
\hline 2. Sebhoric Keratosis & 6 & 4 & 2 & $2: 1$ \\
\hline 3.Bowens disease & 1 & 1 & 0 & --- \\
\hline 4.Squmous cell carcinoma & 41 & 32 & 9 & $3.6: 1$ \\
\hline 5.Basal cell carcinoma & 13 & 5 & 8 & 1:1.6 \\
\hline
\end{tabular}

Table 7: Incidence of Anatomical site of epidermal tumors

\begin{tabular}{|l|c|c|c|}
\hline Anatomical sites & $\begin{array}{l}\text { Tumors of surface } \\
\text { epidermis }\end{array}$ & $\begin{array}{c}\text { Tumors of epidermal } \\
\text { appendages }\end{array}$ & $\begin{array}{c}\text { Tumors of Melanogenic } \\
\text { System }\end{array}$ \\
\hline Head and Neck & 2 & 1 & - \\
Head & 14 & 9 & 4 \\
Face & - & - & - \\
Neck & 1 & & - \\
\hline Trunk & - & - & \\
Chest & 1 & & 2 \\
Back & - & & - \\
Abdomen & & 1 & 5 \\
Pelvis & 4 & - & - \\
\hline Lower extremity & 6 & - & - \\
Thigh\& Buttock & 43 & 1 & 7 \\
Leg & 2 & - & 18 \\
Foot & 4 & 4 & \\
\hline Upper Extremity & 2 & 16 & \\
Axilla & 79 & & \\
Arm & & & \\
Fore arm & & & \\
\hline Unspecified & & & \\
\hline
\end{tabular}

\section{Discussion}

About 1332 are the number of total tumors recorded in the Department of Pathology for a period of 4 years. Out of these No of skin tumors are 114 giving the incidence of $8.6 \%$ and average incidence of 29 per year.(Table 1) Among the total skin tumors of 114, the epidermal tumors are 80 with incidence of $68 \%$. The epidermal tumors are 80 with incidence of $68 \%$ among the total skin tumors.(Table 2) Among the Epidermal tumors the benign tumors in study group are 25 with an incidence of $21.5 \%$ and Malignant tumors are 54 with incidence of 46.44\%.(Table 3) Among the surface epidermal Skin tumors the Benign: Malignant tumors are 1: 2.15.Hence the significance of Diagnosing epidermal tumors is more valuable .The present study Squamous papilloma accounts to $16.34 \%$ Seborrheic Keratosis Accounts 5.16\% ,Bowens disease accounts .86\% Squmous cell carcinoma accounts $35.26 \%$ Basal cell Carcinoma accounts 11.185 among the study group.(Table 4) The present study 19 Squmous papilloma occurred in 4 th decade with $8 \%$ incidence. Seborrhaic Keratosis showed highest incidence in 6 th decade. The Malignant tumors squmous cell carcinoma showing target group of tumor with peak incidence in 5 th decade and basal cell carcinoma the peak age incidence was in the 6 th decade. (Table 5) The present study revealed Squmous cell carcinoma ,Squmous Papilloma are common in male and male and female ratio being 3.6:1, 29:1 respectively. (Table 6)The present study also revealed most common site for the epidermal skin tumors is foot followed by face. (Table 7)Skin tumors have been recognised from the later part of the $19^{\text {th }}$ century. Benign Adnexal tumors occurred much more commonly than the malignant ones. The incidence of patients with skin tumors reporting to the Department of pathology after excision for the Histo Pathology examination which is Confirmatory.

\section{Conclusion}

The Epidermal tumors usually benign, but rarely malignancy. They are usually missed clinically and often confirmed by histo pathology. Immuno histo chemistry may help in confirmation of the Diagnosis. The surface Epidermis tumors were the most common group of neoplasams. out of a total of 1332 samples the skin tumors registered are $114(8.6 \%)$, among them benign tumors in the present study are 25 with incidence of $21.5 \%$, malignant tumors are 54 with an incidence of $46.4 \%$ and second deposits accounted for only one case $(0.8 \%)$.Gold standard rule of Diagnosing the tumors are biopsy or Excision of the tumors and Histopathology examination.Before the conclusion there is still a need for the further research.

\section{References}

[1]. Ackermana's : surgical Pathology-Juan Soai. CCS. Mosby, VII th edition,1990.

[2]. Ali A.EL- domeiri, Richard, D.Brasfield, Annals of D Surgery,Vol 1731,No 1,1971,270-274.

[3]. Andrew, Disease of the Skin, Clinical Dermatology by Anthony,n.Domonskos, W.B.Saunders Company,1971. 
[4]. Balaji Govindan, Clinico- Pathological Study of skin Epidermal and appendageal tumors,IJSR, Volume 5 issue 2, Feb 2016.

[5]. Bean S.F\& Becker F.T.Basal Cell carcinoma of the Vulva-Arch.Dermatol,Sep, No 3,1968.

[6]. Evan'Histological Apperances of Tumors-edited by David J.B.Ashby,III rd Edition,1978.

[7]. Hyman A.B.BarskyA.J. B.C.C of the Palm-Arch, Dermatol,Vol 92,No 6,Nov.P.1571,1965.

[8]. Lever W.F\& G.Schaumberg Lever,HistoPathology of Skin ,VIII Edition,1997.

[9]. Milton R.Okun \& Leon M,Gross and Microscopic Pathology of Skin, Dermatopathology Foundation Press,USA, Vol II,1976.

[10]. Nair PS,A Clinico Pathological Study of Skin appendageal tumors, Indian Journal of Dermatology,Venereol Leprol 2008;74:550.

[11]. Okun M.R. \& G.Blumental,B.C.C with gaint cells and Atypicality- Arch.Dermatol.1964Vol 89,No 4,598.

[12]. Pinkus H\& Amir Mehregag, a guide to Dermatopathology 1969

[13]. R.J.Barr,J.H.Graham,Granular Cell B.C.C ,vol 115,No 9, Sep1979,1064.

[14]. Winter, Benign epidermal Tumors and Proliferations, Clinipathology News letter/2011 